\title{
Effect of Grinding Environment on Galena Flotation
}

\author{
Alireza Javadi Nooshabadi and Kota Hanumantha Rao ${ }^{*}$
} ${ }^{1}$ Mineral Processing Group, Division of Sustainable Process Engineering, Department of Civil, Environmental and
Natural Resources Engineering, Luleå University of Technology, SE-971 87 Luleå, Sweden

${ }^{2}$ Department of Geology and Mineral Resources Engineering, Norwegian University of Science and Technology, No. 7491 Trondheim, Norway

\begin{abstract}
The generation of $\mathrm{H}_{2} \mathrm{O}_{2}$ during the grinding of galena and its effect on the oxidation of galena particles leading to a decrease in flotation recovery has been studied. The influence of two types of grinding media in wet and dry grinding of galena on the formation of hydrogen peroxide and its flotation response was examined. Galena ground in mild steel grinding media generated more hydrogen peroxide compared to stainless steel media. Thus, lower flotation recovery of galena ground in mild steel could also be attributed due to the presence of higher amounts of $\mathrm{H}_{2} \mathrm{O}_{2}$ in the pulp liquid, besides widely reported galvanic interactions between grinding medium and mineral. The extent of galena surface oxidation because of either galvanic interactions or $\mathrm{H}_{2} \mathrm{O}_{2}$ presence or both, is not very clear. Clearly, both mechanisms operate in galena oxidation and needs further investigation to distinguish the predominant mechanism among the two or the extent of each contributing to surface oxidation.
\end{abstract}

Keywords: Galena, Wet and Dry Grinding, Stainless Steel and Mild Steel, Grinding Media, Hydrogen Peroxide, Flotation.

\section{INTRODUCTION}

Galena is the main mineral of lead and it is commonly associated with other sulphide minerals, such as pyrite $\left(\mathrm{FeS}_{2}\right)$, chalcopyrite $\left(\mathrm{CuFeS}_{2}\right)$ and sphalerite $(\mathrm{ZnS})$. Guy and Trahar (1984) reported that the floatability of galena is dependent upon the grinding environment [1] and galena ground in a stainless mill had more recovery than in a steel mill. It was found that the oxidation-reduction environment during grinding is strongly linked to the presence of dissolved iron species from the grinding media [2]. Peng et al. (2003) observed the highest amount of iron species coating on galena particles when ground with mild steel [2]. The dissolved iron ions and their oxidation species played a dominant role in galena flotation. When galena is ground with iron as the grinding medium, galvanic interaction takes place due to a difference in their rest potentials $[3,4]$. The steel grinding medium has a lower potential than galena [5]. The iron medium, which has a lower rest potential will act as the anode and galena with a higher rest potential, will act as the cathode. Electrochemical models have been proposed to explain galvanic interaction between minerals and grinding media [6]. Natarajan and Iwasaki (1984) used the electrochemical models and observed that galvanic

*Address correspondence to this author at the Department of Geology and Mineral Resources Engineering NTNU - Norwegian University of Science and Technology, Sem Sælands vei 1, NO-7491 TRONDHEIM, Norway; Tel: +47-73594837; Fax: +47-73594814;

E-mail: hanumantha.rao.kota@ntnu.no interaction of a mild steel medium with minerals resulted in the formation of iron hydroxide species on the mineral surface [7]. Recently it was revealed that formation of hydrogen peroxide $\left(\mathrm{H}_{2} \mathrm{O}_{2}\right)$, an oxidizing agent stronger than oxygen, takes place in pulp liquid during the wet grinding of complex sulphide ore [8]. Previous works showed that pyrite [9-15] chalcopyrite [14, 16], sphalerite [17] and galena [1821] ground particles generated hydroxyl free radicals interacting with water and thus the formation of $\mathrm{H}_{2} \mathrm{O}_{2}$ in pulp liquid. Pyrite generated more $\mathrm{H}_{2} \mathrm{O}_{2}$ than other sulphide minerals and the order of $\mathrm{H}_{2} \mathrm{O}_{2}$ production by the minerals found to be pyrite $>$ chalcopyrite $>$ sphalerite $>$ galena [22]. Javadi et al. (2013) showed that the mild steel generated more $\mathrm{H}_{2} \mathrm{O}_{2}$ than stainless steel grinding media since the dissolved ferrous ions play a key role in generating higher amounts of $\mathrm{H}_{2} \mathrm{O}_{2}$ [15]. Clearly, hydrogen peroxide oxidizes galena leading to its depression in flotation [23].

In our recent work we found that galena generates $\mathrm{H}_{2} \mathrm{O}_{2}$ in $\mathrm{pH}<4$ [21]. In this study, the results on the effect of two types of grinding media (mild steel and stainless steel) on galena grinding in formation of hydrogen peroxide and its influence on surface oxidation and flotation recovery were presented and discussed.

\section{MATERIALS AND METHODS}

Pure galena sample used in this study was procured from Gregory, Bottley \& Lloyd Ltd., United Kingdom. Galena 


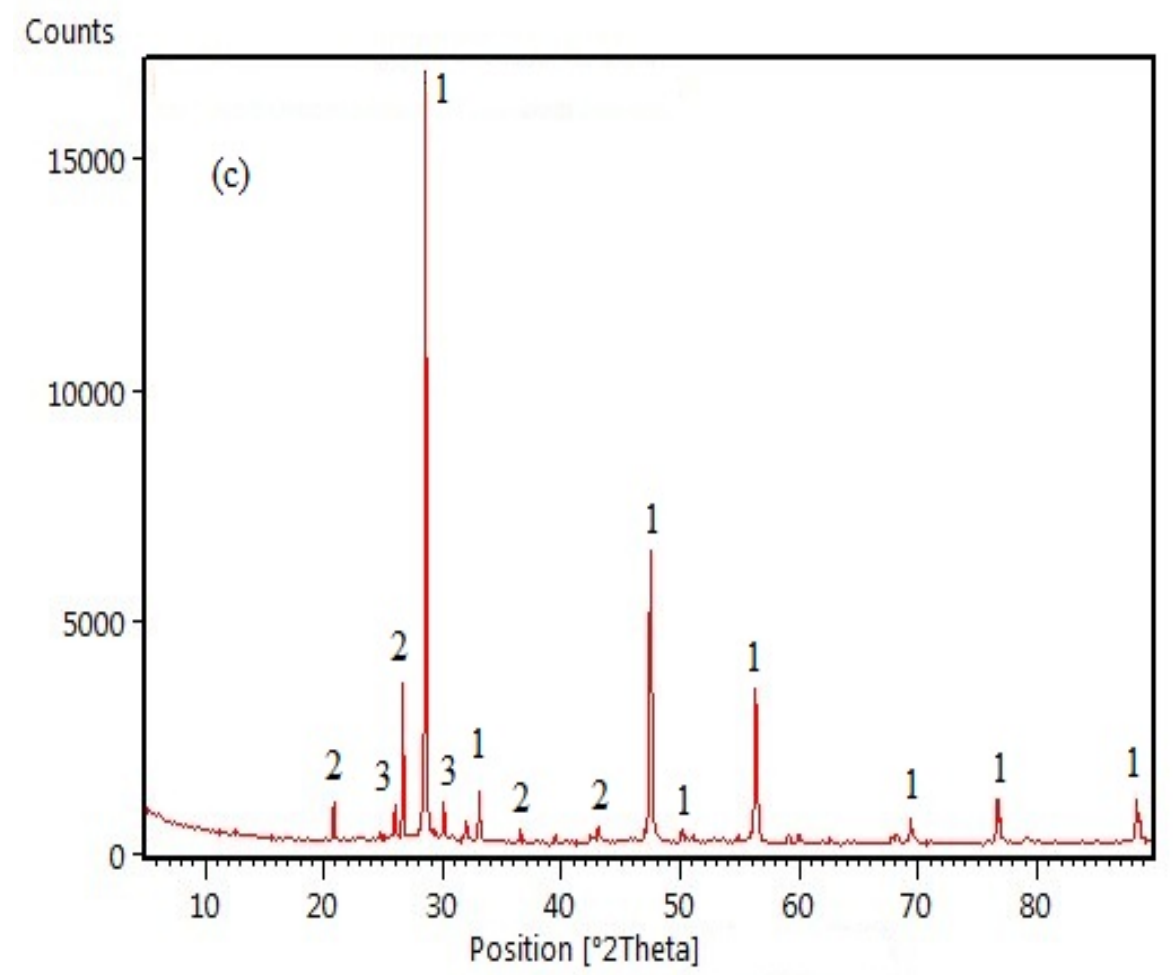

Fig. (1). XRD analysis of the galena sample (1- galena 2- sphalerite 3- quartz).

contains $73.69 \% \mathrm{~Pb}, 13.5 \% \mathrm{~S}, 1.38 \% \mathrm{Fe}, 1.26 \% \mathrm{Zn}, 0.2 \%$ $\mathrm{Cu}$ and some silica (quartz) impurity. The XRD analyses of the sample showed that the main mineral phase present was the galena (Fig. 1). The sample was initially crushed with a jaw crusher and screened to collect the $-3.35 \mathrm{~mm}$ particle size fraction. Homogenised samples of $100 \mathrm{~g}$ each were then sealed in polyethylene bags. All flotation reagents that are being used at the Boliden sulphide mineral beneficiation plant were obtained from Boliden Mineral AB, Boliden, Sweden. Potassium amyl xanthate (KAX) and MIBC were used as collector and frother respectively. Dilute solutions of AR grade sodium hydroxide and $\mathrm{HCl}$ were used to maintain the desired $\mathrm{pH}$ value during flotation. Deionised water was used in both grinding and flotation experiments. Solutions of 2, 9-dimethyl-1, 10-phenanthroline (DMP), copper (II) sulphate $(0.01 \mathrm{M})$ and phosphate buffer $(\mathrm{pH} 7.0)$ used in the analytical method for determining $\mathrm{H}_{2} \mathrm{O}_{2}$ and lead nitrate, ferrous sulphate and ferric sulphate used for investigating the effect of these metal ions on the formation of $\mathrm{H}_{2} \mathrm{O}_{2}$ were purchased from VWR, Sweden.

\section{Wet Grinding and Flotation Tests}

A $100 \mathrm{~g}$ of crushed galena sample of $-3.35 \mathrm{~mm}$ size for each grinding test was combined with $400 \mathrm{ml}$ of water and ground in a new laboratory stainless steel ball mill (Model 2VS, CAPCO Test Equipment, Suffolk, UK) either with stainless steel or mild steel media. The slurry samples during grinding were collected at pre-determined time intervals and they were immediately filtered (Millipore $0.22 \mu \mathrm{m}$ ) and the liquid (filtrate) was analysed for hydrogen peroxide.
After grinding for $60 \mathrm{~min}$, the mill was emptied and the pulp was screened and it was sampled to different portions. In each flotation test, $15 \mathrm{~g}$ sample that was $<75 \mu \mathrm{m}$ was transferred to a cell of $150 \mathrm{ml}$ capacity (Clausthal flotation equipment), conditioned with $\mathrm{pH}$ modifier, collector and frother. The flotation time was $2 \mathrm{~min}$ at an air flow rate of $0.5 \mathrm{dm}^{3} \mathrm{~min}^{-1}$ in each test. The flotation froth was scraped every $10 \mathrm{~s}$ to collect the floated particles. The dosage of collector in flotation was $5 \times 10^{-4} \mathrm{M} \mathrm{KAX}$ and the frother dosage was one drop of MIBC in all the tests, unless otherwise specified. The $\mathrm{pH}$ and collector conditioning of the pulp were $5 \mathrm{~min}$ and $2 \mathrm{~min}$ respectively. All flotation tests were performed at room temperature of approximately $22.5^{\circ} \mathrm{C}$.

\section{Dry Grinding}

One hundred grams of galena was ground in a laboratory stainless steel ball mill with two types of grinding media (mild steel and stainless steel) for $60 \mathrm{~min}$. After grinding, the mill was emptied and the galena was screened from grinding media. A $10 \mathrm{~g}$ of sample that was $<75 \mu \mathrm{m}$ was mixed with $100 \mathrm{~cm}^{3}$ of water in a magnetic stirrer for $5 \mathrm{~min}$. The slurry sample was then collected and analysed for hydrogen peroxide. The $\mathrm{pH}$ was regulated with $\mathrm{HCl}$ or $\mathrm{NaOH}$ solution.

\section{Analysis of Hydrogen Peroxide}

For the amount of hydrogen peroxide formation in pulp liquid, the liquid (filtrate) sample was immediately analysed by spectrophotometric method using copper (II) ions and 


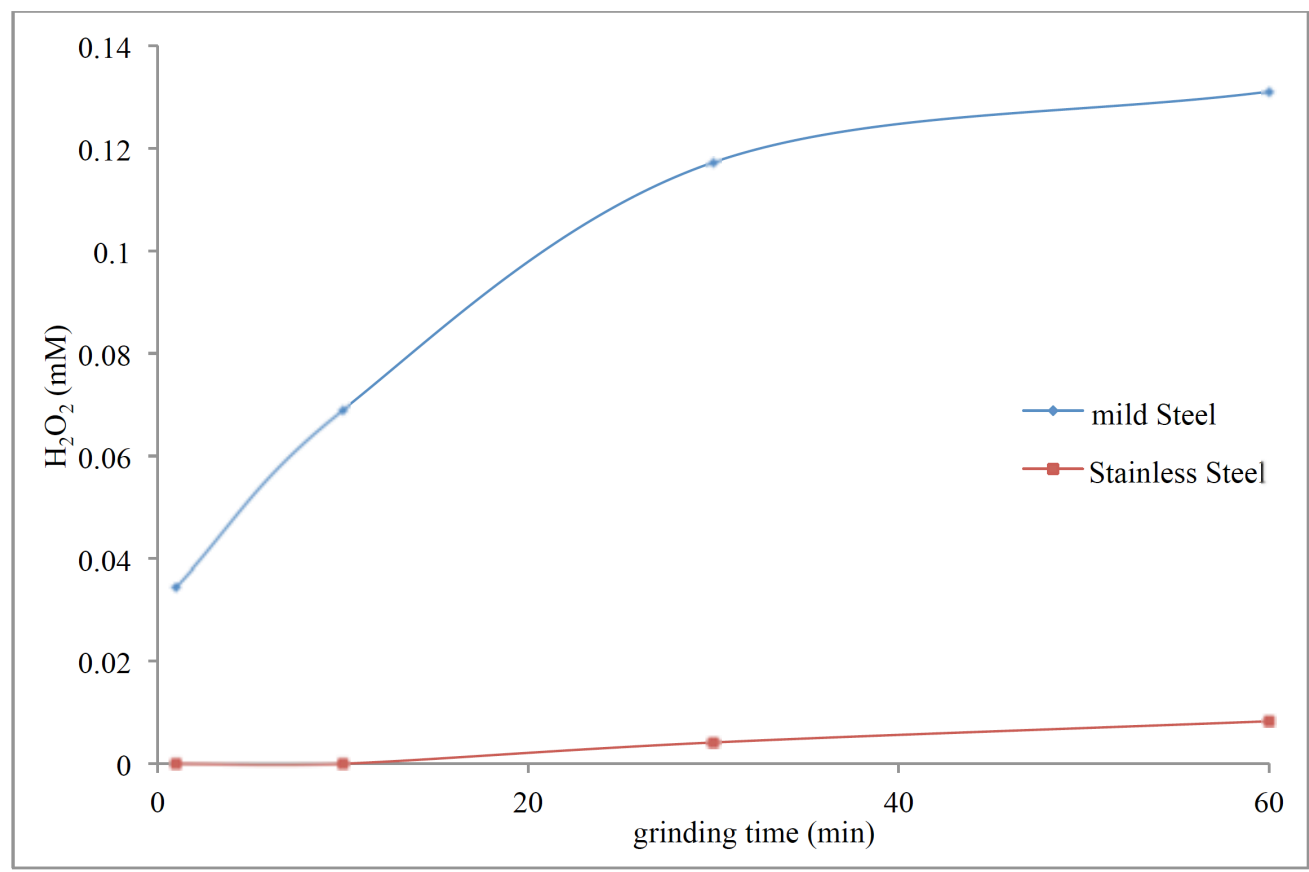

Fig. (2). Production of $\mathrm{H}_{2} \mathrm{O}_{2}$ in pulp liquid as a function of grinding time during wet grinding.

Table 1. Effect of $\mathrm{pH}$ on the flotation recovery of galena with air atmosphere during the flotation.

\begin{tabular}{|c|c|c|}
\hline $\mathbf{p H}$ & Stainless Steel & Mild Steel \\
\hline \hline 4 & 76 & 55 \\
\hline 7 & 86 & 67 \\
\hline 8 & 81 & 57 \\
\hline 9 & 77 & 52 \\
\hline 10 & 68 & 48 \\
\hline
\end{tabular}

DMP [24]. One millilitre each of DMP, copper (II) sulphate, and phosphate buffer $(\mathrm{pH} 7.0)$ solutions were added to a 10 $\mathrm{mL}$ volumetric flask and mixed. $1 \mathrm{ml}$ of liquid (filtrate) sample was added to the volumetric flask, and then the flask was filled with ultrapure water. After mixing, the absorbance of the sample (at $454 \mathrm{~nm}$ ) was measured with DU ${ }^{\circledR}$ Series $700 \mathrm{UV} / \mathrm{Vis}$ Scanning Spectrophotometer. The blank solution was prepared in the same manner but without $\mathrm{H}_{2} \mathrm{O}_{2}$.

\section{RESULTS}

Formation of Hydrogen Peroxide $\left(\mathrm{H}_{2} \mathrm{O}_{2}\right)$ During Wet Grinding and its Implications for Flotation

The effect of the nature of grinding media on the formation of hydrogen peroxide during wet grinding of galena was investigated. The galena was wet-ground in a laboratory stainless steel ball mill with two kinds of grinding media at natural $\mathrm{pH}$ and slurry samples were collected at a pre-determined time intervals. The slurry samples were filtered (Millipore $0.22 \mu \mathrm{m}$ ), and the liquid (filtrate) was analysed for hydrogen peroxide. Fig. (2) shows the effect of grinding media on the formation of hydrogen peroxide where mild steel produced a higher concentration of $\mathrm{H}_{2} \mathrm{O}_{2}$ than stainless steel medium. Mild steel grinding medium was known to produce dissolved iron ions and thereby several hydrolysed iron species that adsorb on galena particles [2]. Dissolved $\mathrm{Fe}^{2+}$ ions also react with dissolved molecular oxygen via Haber-Weiss reaction mechanism and forms superoxide anion $\left(\mathrm{O}_{2}{ }^{\circ}\right)^{-}$(eq. 1), which reacts with ferrous iron to form $\mathrm{H}_{2} \mathrm{O}_{2}$ (eq. 2) [11].

$\mathrm{Fe}^{2+}+\mathrm{O}_{2} \rightarrow \mathrm{Fe}^{3+}+\left(\mathrm{O}_{2}^{\circ}\right)^{-}$

$\mathrm{Fe}^{2+}+\left(\mathrm{O}_{2}^{\circ}\right)^{-+} 2 \mathrm{H}^{+} \rightarrow \mathrm{Fe}^{3+}+\mathrm{H}_{2} \mathrm{O}_{2}$

This was in agreement with other studies where mild steel produced a higher concentration of $\mathrm{H}_{2} \mathrm{O}_{2}$ than stainless steel medium during grinding of pyrite [16]. By realizing the formation of $\mathrm{H}_{2} \mathrm{O}_{2}$ in the pulp liquid, the effect of this strong oxidizing agent on solid surfaces and its consequences for flotation have been addressed below.

The effect of grinding media type after 60 min grinding on the flotation recovery of galena was investigated. Table $\mathbf{1}$ 


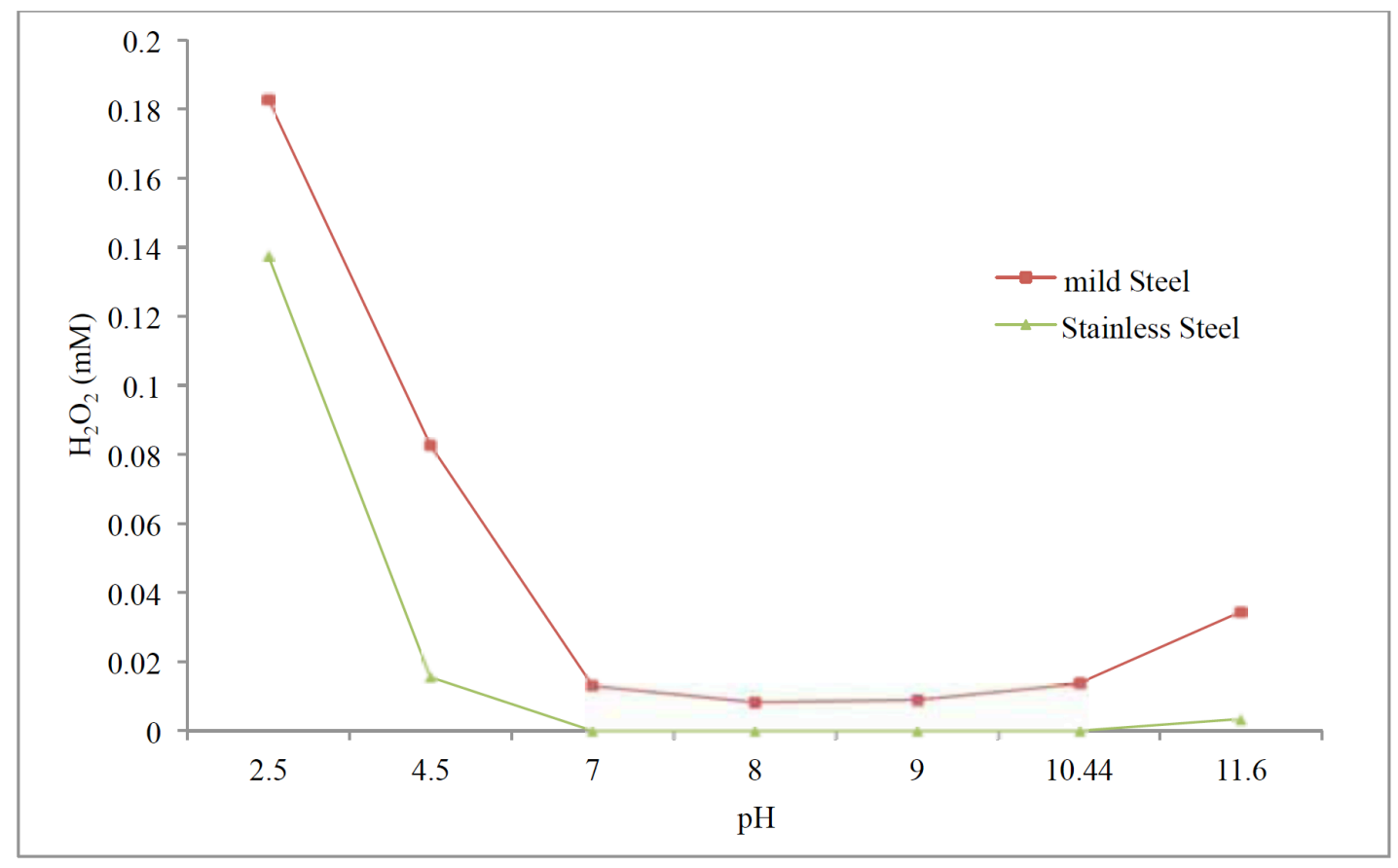

Fig. (3). Formation of $\mathrm{H}_{2} \mathrm{O}_{2}$ in pulp liquid as a function of grinding time during wet grinding.

shows the effect of grinding media type on galena recovery. It can be seen that the galena wet-ground with mild steel media has a lower galena recovery than galena wet-ground with stainless steel media. This is in good agreement with other studies where $30 \mathrm{wt} \%$ chromium medium produced a much higher galena flotation recovery than the mild steel medium [25]. Since wet-ground galena with mild steel media produces higher amount of $\mathrm{H}_{2} \mathrm{O}_{2}$, a decrease in galena recovery could be due to surface oxidation caused by $\mathrm{H}_{2} \mathrm{O}_{2}$ oxidant. Ikumapayi et al. (2012) showed the presence of surface oxidized species such as sulfoxy and hydroxyl species on galena. [26]. Wang (2002) reported that the addition of $\mathrm{H}_{2} \mathrm{O}_{2}$, galena flotation decreases and completely depresses if the concentration of $\mathrm{H}_{2} \mathrm{O}_{2}$ exceeds $10^{-3} \mathrm{M}$ [23]. $\mathrm{He}$ attributes this strong depressing action of $\mathrm{H}_{2} \mathrm{O}_{2}$ on galena to its strong oxidising action on lead xanthate in the galena surface which gives rise to the oxidation and decomposition of lead xanthate (eq. 3) [23].

$\left[\mathrm{Pb}(\mathrm{EX})_{2}\right]_{\mathrm{ads}}+\mathrm{H}_{2} \mathrm{O}_{2} \rightarrow \mathrm{Pb}(\mathrm{OH})_{2}+(\mathrm{EX})_{2}$

\section{Formation of Hydrogen Peroxide $\left(\mathrm{H}_{2} \mathrm{O}_{2}\right)$ after Dry Ground Solids are Placed in Water}

The effect on the type of grinding media during dry grinding on the formation of hydrogen peroxide when the dry ground solids are placed in water was investigated. The galena was dry-ground in a laboratory stainless steel ball mill with two kinds of grinding media. Afterwards, the dry

ground solids were mixed with water for $5 \mathrm{~min}$. The liquid (filtrate) was analysed for hydrogen peroxide and the results are shown in Fig. (3). It can be seen that at all $\mathrm{pH}$ levels mild steel generated a higher concentration of $\mathrm{H}_{2} \mathrm{O}_{2}$ than stainless steel medium. These results correspond to the results of wet grinding (Fig. 2).

\section{DISCUSSION}

Tao (2004) used Eh-pH diagram to demonstrate that Mild steel medium corrodes under reducing and moderately oxidizing conditions (Fig. 4a,b) [27]. The oxidation of Mild steel yields $\mathrm{Fe}^{2+}$ species at acid weak $(\mathrm{pH}<6)$ and with a decreasing $\mathrm{pH}, \mathrm{Fe}^{2+}$ species increase in solution and these ferrous ions generate superoxide anion $\left(\mathrm{O}_{2}{ }^{\circ}\right)^{-}$in the presence of dissolved molecular oxygen (eq. 1), which reacts with ferrous iron to form $\mathrm{H}_{2} \mathrm{O}_{2}$ (eq. 2) [11].

Under neutral and mildly alkaline conditions, Mild steel medium does not corrode, because it is either immune under strongly reducing conditions or is in a passive state for more oxidizing conditions. In strong alkaline environments, Mild steel is free from corrosion except for a small region of potentials and $\mathrm{pHs}$ where soluble, alkaline, corrosion products form [27].

Tao (2004) also showed by Eh-pH diagram that stainless steel medium does not corrode in strongly reducing or oxidizing conditions except when the $\mathrm{pH}$ values are below 3 [27], in which case, the stainless steel is more stable than mild steel.

The proposed mechanisms of $\mathrm{H}_{2} \mathrm{O}_{2}$ generation are shown in Fig. (5) where $\mathrm{Fe}^{2+}$ ions formed by mild steel are responsible for generating $\mathrm{H}_{2} \mathrm{O}_{2}$. 


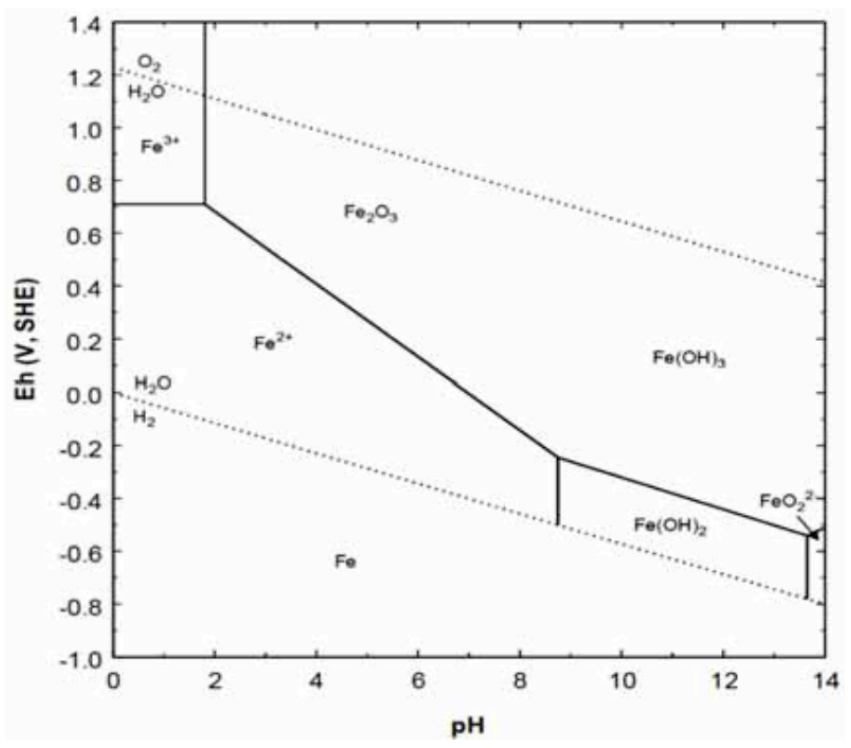

a

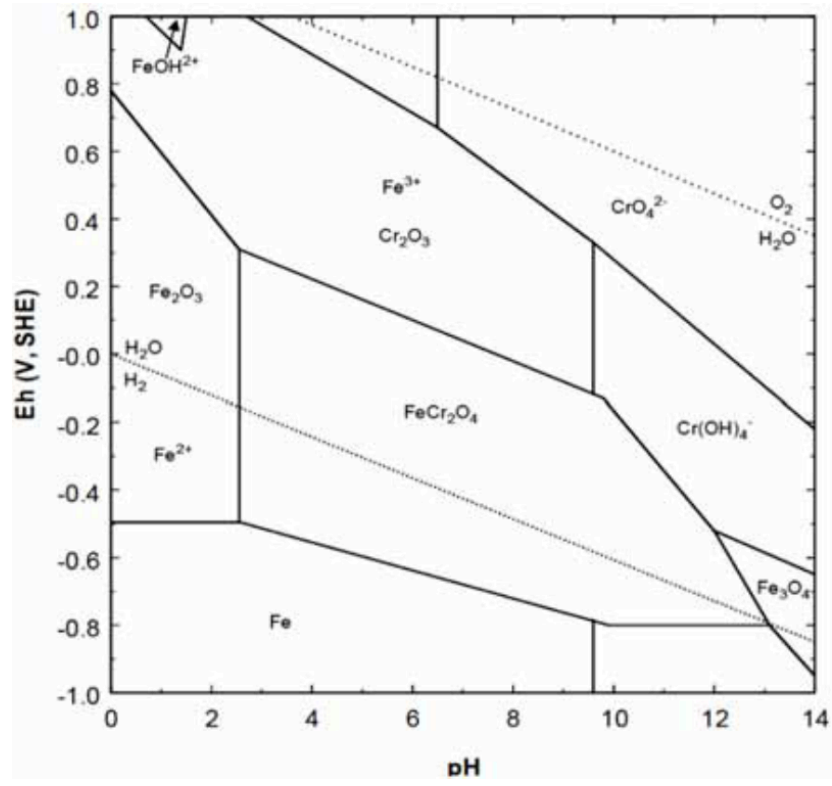

b

Fig. (4a). Eh-pH Diagram for Fe-O-H System, Assuming $\mathrm{Fe}(\mathrm{OH})_{3}$ as Stable $\mathrm{Fe}^{3+}$ Phase and Activity of Dissolved $\mathrm{Fe}=10^{-6} \mathrm{M}$. b) Eh-pH Diagram for Fe-Cr- $\mathrm{H}_{2} \mathrm{O}$ System, Assuming Total Concentrations of $10^{-2} \mathrm{M} \mathrm{Fe}$ and $5 \times 10^{-3} \mathrm{M} \mathrm{Cr}$ [27].
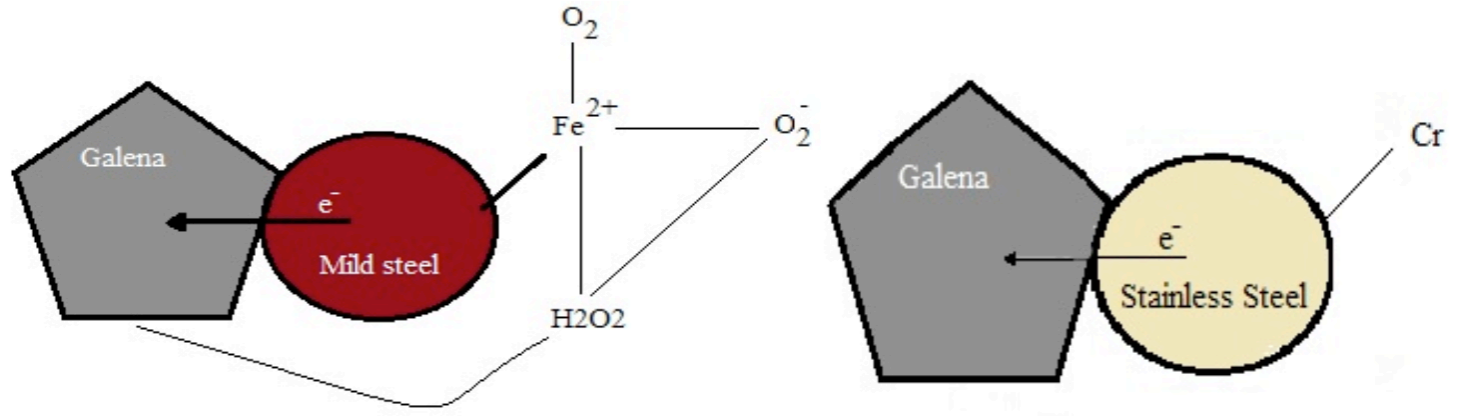

Fig. (5). Production of $\mathrm{H}_{2} \mathrm{O}_{2}$ by galena in contact with a) Mild steel and b) Stainless steel by the incomplete reduction of oxygen (eqs. 1 and 2). 


\section{CONCLUSION}

The formation of $\mathrm{H}_{2} \mathrm{O}_{2}$ in pulp liquid during galena grinding is more in mild steel grinding media than stainless steel and with increasing grinding time, the concentration of $\mathrm{H}_{2} \mathrm{O}_{2}$ increased. More flotation recovery of galena ground in stainless steel than mild steel medium is obviously due to a lower concentration of hydrogen peroxide, which acts as a strong depressant for galena.

\section{CONFLICT OF INTEREST}

The authors declare that there is no conflict of interest regarding the publication of this article.

\section{ACKNOWLEDGEMENTS}

Financial support from the research Centre for Advanced Mining and Metallurgy (CAMM), Luleå University of Technology, Luleå, Sweden, and Boliden Mineral AB, Boliden, Sweden, is gratefully acknowledged.

\section{REFERENCES}

[1] P. Guy and W. Trahar, "The influence of grinding and flotation environments on the laboratory batch flotation of galena," Int. J. Miner. Process, vol. 12, pp. 15-38, 1984.

[2] Y. Peng, S. Grano, D. Fornasiero and J. Ralston, "Control of grinding conditions in the flotation of galena and its separation from pyrite," Int. J. Miner. Process, vol. 70, pp. 67-82, 2003.

[3] S. Rao, K. Moon and L. J., "Effect of grinding media on the surface reactions and flotation of heavy metal sulphides," In: Flotation, A.M. Gaudin Memorial, Marcel Dekker: New York 1976, pp. 509527.

[4] S. Rao, G. Labonte and J. Finch, "Electrochemistry in the plant," In: Innovations in Flotation Technology, Greece, 1992.

[5] Y. Penga and S. Grano, "Effect of iron contamination from grinding media on the flotation of sulphide minerals of different particle size," Int. J. Miner. Proc., vol. 97, no. 1-4, pp. 1-6, 2010.

[6] K. Adam, K. Natarajan, S. Riemer and I. Iwasakim, "Electrochemical aspects of grinding media-mineral interaction in sulphide ore grinding," Corrosion (Houston), vol. 42, pp. 440-447, 1986.

[7] K. Natarajan and I. Iwasaki, "Electrochemical aspects of grinding media-mineral interactions in magnetite ore grinding," Int. J. Miner. Process., vol. 13, pp. 53-71, 1984.

[8] F. Ikumapayi, H. Sis, B. Johansson and K. Hanumantha Rao, "Recycling process water in sulphide flotation, Part B: Effect of $\mathrm{H}_{2} \mathrm{O}_{2}$ and process water components on sphalerite flotation from complex sulphide," Miner. Metall. Process, vol. 29, pp. 192-198, 2012.

[9] M. Borda, A. Elsetinow, M. Schoonen and D. Strongin, "Pyriteinduced hydrogen peroxide formation as a driving force in the evolution of photosynthetic organisms on an early Earth," Astrobiology, vol. 1, pp. 283-288, 2001.

[10] M. Borda, A. Elsetinow, D. Strongin and M. Schoonen, "A mechanism for the production of hydroxyl radical at surface defect sites on pyrite," Geochim. Cosmochim. Acta, vol. 67, no.5, pp. 935 $-939,2003$

[11] C. Cohn, S. Mueller, E. Wimmer, N. Leifer, S. Greenbaum, D. Strongin and M. Schoonen, "Pyrite-induced hydroxyl radical formation and its effect on nucleic acids," Geochem. Trans., vol.7, p.1, 2006.

[12] G. Jones, K. Corin, R. van Hille and S. Harrison, "The generation of toxic reactive oxygen species (ROS) from mechanically activated sulphide concentrates and its effect on thermophilic bioleaching," Miner. Eng., vol. 24, pp. 1198-1208, 2011.

[13] G. Jones, R. van Hille and S. Harrison, "Reactive oxygen species generated in the presence of fine pyrite particles and its implication in thermophilic mineral bioleaching," Appl. Microbiol. Biotechnol., vol. 97, pp. 2735-2742, 2013.

[14] G. Jones, B. Megan, R. van Hille and S. Harrison, "The effect of sulphide concentrate mineralogy and texture on Reactive Oxygen Species (ROS) generation," Appl. Geochem., vol. 29, pp. 199-213, 2013.

[15] A. Javadi, A. Larsson and K. Hanumantha Rao, "Formation of hydrogen peroxide by pyrite and its influence on flotation," Min. Eng., vol. 49, pp. 128-134, 2013.

[16] A. Javadi and K. Hanumantha Rao, "Formation of hydrogen peroxide by chalcopyrite and its influence on flotation," Miner. Metallurg. Proc., vol. 30, no. 4, pp. 212-219, 2013.

[17] A. Javadi and K. Hanumantha Rao, "Formation of hydrogen peroxide by sphalerite," Int. J. Miner. Process., vol. 125, pp. 78-85, 2013.

[18] E. Ahlberg and A. Broo, "Oxygen reduction at sulphide minerals. 1. A rotating ring disc electrode (RRDE) study at galena and pyrite," Int. J. Miner. Process., vol. 46, pp. 73-89, 1996.

[19] E. Ahlberg and A. E. Broo, "Oxygen reduction at sulphide minerals. 2. A rotating ring disc electrode (RRDE) study at galena and pyrite in the presence of xanthate," Int. J. Miner. Process, vol. 47, p. 33- 47, 1996.

[20] E. Ahlberg and A. E. Broo, " Oxygen reduction at sulphide minerals. 3. The effect of surface pre-treatment on the oxygen reduction at pyrite," Int. J. Miner. Process, vol. 47, no. 1-2, pp. 4960, 1996.

[21] A. Javadi Nooshabadi and Hanumantha Rao Kota, "Formation of hydrogen peroxide by galena and its influence on flotation," $A d v$. Powder Technol., vol. 25, no. 3, pp. 832-839, 2014.

[22] A. Javadi Nooshabadi and K. Hanumantha Rao, "Formation of hydrogen peroxide by sulphide minerals," Hydrometallurgy, vol. 141, pp. 82-88, 2014.

[23] D. Wang, "Potential Adjustment of Sulphide Mineral and Collectorless Flotation. In: New Development of Flotation Theory," Beijing: Science Press, 1992, pp. 79-143.

[24] K. Kosaka, H. Yamada, S. Matsui, S. Echigo and K. Shishida, "A comparison among the methods for hydrogen peroxide measurements to evaluate advanced oxidation processes: application of a spectrophotometric method using copper (II) ion and 2, 9-Dimethyl-1, 10-phenanthroline," Environ. Sci. Technol., vol. 32, pp. 3821-3824, 1998.

[25] Y. Peng, S. Grano, J. Ralston and D. Fornasiero, "Towards prediction of oxidation during grinding I. Galena flotation," Miner. Eng., vol. 15, pp. 493-498, 2002.

[26] F. Ikumapayi, M. Makitalo, B. Johansson and K. Hanumantha Rao, "Recycling of process water in sulphide flotation: Effect of calcium and sulphate ions on flotation of galena," Miner. Eng., vol. 39, pp. 77-88, 2012a.

[27] D. Tao, "Corrosion Protection of Grinding Mills in the Phosphate Industry Using Impressed Current Technology," Florida Institute of Phosphate Research, Bartow, FL 33830 USA, 2004. 